\title{
High-mountain lakes as indicators of microplastic pollution: current and future perspectives
}

\author{
Paolo Pastorino', Marino Prearo1, Elisabetta Pizzul', Antonia Concetta Elia ${ }^{3}$, Monia Renzi ${ }^{2}$, Antoni \\ Ginebreda ${ }^{4}$, Damià Barceló ${ }^{4,5}$ \\ 'The Veterinary Medical Research Institute for Piemonte, Liguria and Valle d'Aosta, Torino 10154, Italy. \\ ${ }^{2}$ Department of Life Sciences, University of Trieste, Trieste 34127, Italy. \\ ${ }^{3}$ Department of Chemistry Biology and Biotechnology, University of Perugia, Perugia 06123, Italy. \\ ${ }^{4}$ Department of Environmental Chemistry, Institute of Environmental Assessment and Water Research (IDAEA-CSIC), Barcelona \\ 08034, Spain \\ ${ }^{5}$ Catalan Institute for Water Research (ICRA-CERCA), Girona 17003, Spain.
}

Correspondence to: Dr. Paolo Pastorino, Aquatic Biology Lab, The Veterinary Medical Research Institute for Piemonte, Liguria and Valle d'Aosta, Via Bologna 148, Torino 10154, Italy. E-mail: paolo.pastorino@izsto.it

\begin{abstract}
How to cite this article: Pastorino P, Prearo M, Pizzul E, Elia AC, Renzi M, Ginebreda A, Barceló D. High-mountain lakes as indicators of microplastic pollution: current and future perspectives. Water Emerg Contam Nanoplastics 2022;1:3.

https://dx.doi.org/10.20517/wecn.2022.01
\end{abstract}

Received: 12 Jan 2022 First Decision: 29 Jan 2022 Revised: 6 Feb 2022 Accepted: 14 Feb 2022 Published: 18 Feb 2022

Academic Editors: Leobardo Manuel Gómez-Oliván, Defeng Xing Copy Editor: Xi-Jun Chen Production Editor: Xi-Jun Chen

\begin{abstract}
As a key component of mountain ecosystems, high-mountain lakes are recognized indicators of global change. In the analysis of the effects induced by local or global human activities, microplastic (MP) pollution is of critical environmental concern for mountain ecosystem compartments and for high-mountain lakes in particular. This minireview reports on current knowledge of MP occurrence, source, distribution, and characteristics in highmountain lake ecosystems. The literature search returned only nine studies mainly from the Tibet plateau (China). Generally, the two most often investigated compartments were water and sediment, followed by snow and fish. Plastic particles were found as fragments and fibers of polypropylene and polyethylene, which are primarily utilized in food packaging and supplies brought by tourists and then discarded on site. Tourism and atmospheric longrange transport from lowlands were identified as the main sources of MP pollution. Precipitation events (snow and rain) were reported as key events in MP deposition and fallout. Further studies are needed to better understand the effects of MP pollution on aquatic food webs and ecosystem resources (e.g., drinking water) in these key ecosystems.
\end{abstract}


Keywords: Atmospheric transport, fibers, fragments, polyethylene, polypropylene, tourism

\section{INTRODUCTION}

High-mountain lakes share numerous similarities ${ }^{[1]}$, the foremost of which are pristine naturalness and environmental constraints ${ }^{[2]}$ : low water temperature, low nutrient concentration (e.g., of phosphorus), and prolonged ice cover all limit primary production ${ }^{[3]}$. Here, the food webs are simpler than those of lakes located at lower altitudes. Many are relatively shallow, shortening the theoretical time of water change to a few days during the late spring-summer thaw ${ }^{[4]}$. Deep mountain lakes are generally dimictic with two periods of stratification: one direct in summer and the other inverse under the winter ice cover ${ }^{[4]}$. Since mountainous rock is resistant to erosion, lake waters are poorly mineralized and have a low buffering capacity against acid loads, which is the reason for the low total alkalinity ${ }^{[5]}$. Although mountain lakes are generally much less influenced by human activity than other habitats, global and local anthropogenic threats can alter their natural environment. The most serious are water exploitation ${ }^{[6]}$, alien species introduction ${ }^{[7]}$, climate change ${ }^{[8]}$, and medium- to long-range atmospheric transport of contaminants ${ }^{[0-11]}$.

Microplastics are emerging contaminant $\mathrm{s}^{[12]}$, increasingly found also in these pristine ecosystems ${ }^{[13]}$. Plastics generate an enormous quantity of waste: about $70 \%$ of the world's plastic is recycled or reused for energy production, while the remaining $30 \%$ is transported to landfills and, together with the plastic waste, directly released into the environment, where it contaminates the soil, rivers, lakes, and ultimately the ocean $s^{[14-16]}$. The world's annual production of plastics was 1.7 million tons in the $1950 \mathrm{~s}^{[17]}$, totaling 368 million tons in 2019, 57.9 million tons (16\%) of which was produced in Europe ${ }^{[18]}$. In the first decade of this century, plastic production equaled the total amount generated in the previous century, characterizing our current era as the "Age of Plastic" ${ }^{[19]}$. Plastics break down physically into smaller and smaller fractions, termed microplastics (MPs, $1 \mu \mathrm{m}-5 \mathrm{~mm})^{[20]}$. Microplastics are characterized by stable chemical properties, small size, and low density and are classified as primary and secondary ${ }^{[21]}$. Primary MPs are manufactured plastic particles that go into a variety of products (e.g., cosmetics), while secondary MPs are formed during the use and disposal of plastic products (e.g., degradation of plastic bottles) or in the decomposition of macroplastics into $\mathrm{MPs}^{[22]}$.

The degradation of plastic wastes is thought to be an important factor in the creation of $\mathrm{MPs}^{[23]}$. Degradation of synthetic polymers can generally be classified as biotic or abiotic, following different mechanisms, depending on a variety of physical, chemical, or biological factors. Abiotic degradation of plastics is defined as a change in physical or chemical qualities caused by abiotic elements such as light, temperature, air, water, and mechanical forces ${ }^{[22]}$. Instead, biotic degradation refers to the deterioration of plastics caused by organisms ${ }^{[23]}$. Organisms can degrade plastics either physically by biting, chewing, or digestive fragmentation ${ }^{[24]}$ or biologically by biochemical processes ${ }^{[25]}$. Microorganisms, including bacteria, fungi, and insects, are mainly responsible for the biological degradation of plastics ${ }^{[26]}$. Even though knowledge of environmental degradation of plastics and creation of MPs is currently limited and requires improved understanding, it is crucial in determining their fate and impacts ${ }^{[23]}$.

Surface runoff ${ }^{[27]}$, atmospheric deposition ${ }^{[28]}$, discharge from wastewater treatment plants (WWTPs) $)^{[22]}$, and decomposition of large plastic materials represent the main sources of MPs in freshwater ${ }^{[24,30]}$. According to the literature, up to $80 \%$ of MPs in freshwater watercourses come from drainage following treatment at $W_{W T P} s^{[31]}$. For example, Murphy et al ${ }^{[32]}$ investigated the effluent of a large secondary sewage treatment plant (daily treatment capacity $260.954 \mathrm{~m}^{3}$ ) in Glasgow (Scotland) and discovered that, despite a final MP removal rate of $98.41 \%$, approximately $6.5 \times 10^{7}$ particles of MPs were discharged into the aquatic 
environment every day. Furthermore, rainfall-induced surface runoff is the primary means of transporting different plastics from land to surface water ${ }^{[3,3,3]}$. According to a recent study, the highest concentration of MPs (66-191 particles/L) occurred during periods of heavy rainfall ${ }^{[35]}$. After heavy rain, the highest

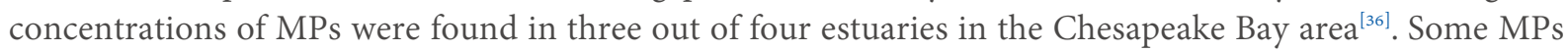
that enter surface waters are trapped in sediments, while others continue to be transported downstream, ending up into the seas and oceans where currents bring MPs further out to sea and/or closer to land ${ }^{[36]}$. Ocean circulation patterns, marine currents, and MP drift have also been identified as key drivers of plastic dispersal in the Arctic environment ${ }^{[37]}$.

Several plastic particles are also released in the atmosphere. These fibers can be transported to far areas by the wind, where they can then be dry or wet deposited on land or in water $^{[33,38]}$. On this path, it is well documented how MPs can reach remote and pristine ecosystems, even when there are no local point sources of plastic ${ }^{[13]}$. These findings, taken together, are noteworthy because they emphasize the broad spatiotemporal dimensions of the processes that determine the sources, fate, and effects of MPs on the environment, including humans. Indeed, because they are ubiquitous (oceans, surface waters, wastewaters, soils, sediments, atmosphere, food, etc.), they impact on environmental and human health ${ }^{[39]}$.

The high surface area and hydrophobicity of MPs facilitate their ingestion by both terrestrial and aquatic organisms and increase the risks of toxic chemical and pathogens adsorption and desorption in water, with possible negative consequences not only for humans but also for the biodiversity ${ }^{[40]}$.

The question arises about the MP pollution of high-mountain lakes, which are recognized sentinels of global change and ecosystem sensors in the analysis of the effects of local and global human activities on biocenoses and biodiversity (e.g., alien species and contaminants ${ }^{[1-4]}$. They also constitute a natural laboratory for basic ecological studies in mountainous regions sensitive to global climate change, representing a good candidate as indicators of MP pollution ${ }^{[13]}$. Thus, this minireview seeks to answer the question by summarizing recent research into these highly comparable ecosystems.

\section{LITERATURE SEARCH}

We queried the electronic databases Google Scholar (https://scholar.google.it/) and Scopus (https://www.scopus.com/) first using the search terms "mountain" AND "microplastics" OR "plastic" to retrieve studies on MPs source and transport in mountain environments. We then repeated the search using the terms "mountain lakes" OR "altitude lakes" AND "microplastics" OR "plastic" to narrow the search to the occurrence of MPs in high-mountain lakes sensu stricto ${ }^{[1]}$. The first query yielded about 116 records and the second retrieved only nine studies on MPs in high-mountain environments.

\section{SOURCE OF MICROPLASTICS IN MOUNTAIN ENVIRONMENTS}

The source of MPs in high-mountain ecosystems is human activities and atmospheric conditions with seasonal variability ${ }^{[4]}$. The principal drivers of MP deposition are primarily atmospheric transport from an urban point source ${ }^{[38]}$ and precipitation events (rain and snow) ${ }^{[13,42]}$. Snow works as a scavenger, trapping pollutants and particulate matter in the atmosphere, which is carried by atmospheric transport (wind, storm, and/or rain), and then deposited on the ground. Due to their low density, MPs are lifted into the upper layers of the atmosphere by wind currents, and then deposited by snowfall or rainfall in higher altitude habitats where they may pose environmental risks ${ }^{[43]}$. Microplastics can readily reach isolated ecosystems and propagate into terrestrial and aquatic ecosystems ${ }^{[44]}$. Through atmospheric transport and deposition, MPs have been found in such remote ecosystems as the polar regions of the $\operatorname{Arctic}^{[37]}$, the deepsea environment ${ }^{[45]}$, sea surfaces ${ }^{[46]}$, and glaciers ${ }^{[47-49]}$. 
Microplastic pollution can remain in glaciers indefinitely since they are trapped in snow deposits in high alpine areas ${ }^{[4]}$. As the glaciers melt, they release MPs into freshwater and marine systems ${ }^{[47]}$. Supraglacial debris is typically high in MPs deposited by wind or snow, and the glacial flow transports the imbedded MPs and other contaminants down the valley, where they accumulate downstream in rivers or lakes ${ }^{[50]}$.

Microplastics can also be introduced into remote environments, mountainous terrains and foothills, and high-mountain lakes by the deterioration and fragmentation of plastic items washed up on beaches and then carried back into the sea by the wind ${ }^{[51]}$. In large cities, because MPs are aerosolized pollutants, they are quantified by source-specific and remote atmospheric sampling ${ }^{[52]}$. Finally, MPs have been found in a variety of remote ecosystems, indicating that they travel from major industrial areas or other anthropogenic sources via medium- to long-range transport from low-lying locations ${ }^{[3,38,5,3,54]}$.

Studies investigating MP pollution in extreme environments have shown that Mount Everest (8850 m above sea level) $)^{[55]}$ and the Vatnajökull Ice Cap, which were long thought to be clean, are contaminated ${ }^{[56]}$. Mountain climbers and trekkers typically wear clothing made from synthetic textiles, and MP fibers shed by synthetic fabrics may be a source of direct MP deposition ${ }^{[47]}$. Many synthetic fibers, such as polyesters and polyamides from tourist garments, are regularly found in remote regions ${ }^{[47,48]}$. Figure 1 illustrates the potential sources of MPs and their transport to high-mountain ecosystems.

\section{MICROPLASTICS OCCURRENCE IN HIGH-MOUNTAIN LAKES}

The literature search retrieved only nine studies on MP occurrence in high-mountain lakes (altitude > $1500 \mathrm{~m}$ a.s.l.), mainly from the Tibet plateau (China). Table 1 presents the country, altitude, sample(s) type, sampling method(s), detection, polymer(s), shape, size, color, abundance, and potential MPs source reported by each study. The most often investigated matrix was abiotic samples, mainly sediment and water. Although aquatic high-altitude environments are populated by native macroinvertebrates, only two studies investigated other biotic matrices (e.g., non-native fish) ${ }^{[13,57]}$. Stainless steel tools for sediment and trawl/plankton nets for water were typical sampling instruments ${ }^{[58]}$.

In the studies here analyzed, stereomicroscopy was generally used to determine particle color and morphology and Fourier-transform infrared spectroscopy (FTIR) to identify chemical type. Stereomicroscope, FTIR, scanning electron microscopy (SEM), pyrolysis-gas chromatography-mass spectroscopy (Pyr-GC/MS), and Raman spectroscopy are commonly employed for identification and quantification of $\mathrm{MPs}^{[58]}$. Stereomicroscope cannot accurately distinguish between natural and synthetic particles. On this path, Free et al. ${ }^{[33]}$ used a light microscope to detect MPs; however, this method is operator-dependent and can result in wide variation between observers ${ }^{[8]}$. For instance, direct visual detection of MPs in beach sediments by multiple observers varied between $60 \%$ and $100 \%$ depending on operator experience and fatigue and leading to overestimation (biologic material mistaken for black fragments) or underestimation (white fragments) of certain types and colors of $\mathrm{MPs}^{[59]}$. Misclassification of other material as plastics, confirmed by subsequent chemical analysis, was reported for about $70 \%$ of presumed $\mathrm{MPs}^{[60]}$. Thus, it is highly recommended to utilize both microscopy and other analytical methods to identify the target samples. SEM is also a common instrument used in identification of MPs. In particular, the combination of SEM and energy-dispersive X-ray spectroscopy (SEM-EDS) can provide information on the elemental composition of particles. FTIR and Raman spectroscopy are typically used to characterize MPs and identify their polymer types, while Pyr-GC/MS can determine the chemical composition of MPs with additive. However, this method is time-consuming and destructive. Thus, FTIR and Raman spectroscopy are highly recommended ${ }^{[58]}$. 
Table 1. Microplastics occurrence in high-mountain lakes worldwide

\begin{tabular}{|c|c|c|c|c|c|c|c|c|c|c|c|c|}
\hline Country & Lake & $\begin{array}{l}\text { Altitude } \\
\text { (m a.s.I.) }\end{array}$ & Sample type & $\begin{array}{l}\text { Sampling } \\
\text { method }\end{array}$ & $\begin{array}{l}\text { Detection } \\
\text { techniques }\end{array}$ & Polymer(s) & Abundance & $\begin{array}{l}\text { Dominant } \\
\text { Shape }\end{array}$ & $\begin{array}{l}\text { Size } \\
(\mu \mathrm{m})\end{array}$ & Colour(s) & $\begin{array}{l}\text { Potential } \\
\text { source }\end{array}$ & Ref. \\
\hline \multirow[t]{12}{*}{ China } & $\begin{array}{l}\text { Gangtang } \\
\text { Co }\end{array}$ & 4872 & \multirow[t]{12}{*}{ Sediment } & \multirow[t]{12}{*}{$\begin{array}{l}\text { Stainless-steel } \\
\text { tools }\end{array}$} & \multirow[t]{12}{*}{$\begin{array}{l}\text { Stereomicroscope, } \\
\text { FTIR }\end{array}$} & \multirow[t]{12}{*}{ PA, PET } & $\begin{array}{l}406.85 \pm \\
262.18 \text { items/kg }\end{array}$ & \multirow[t]{12}{*}{$\begin{array}{l}\text { Fibres, films, } \\
\text { fragments }\end{array}$} & \multirow[t]{12}{*}{$\begin{array}{l}50- \\
500\end{array}$} & \multirow{12}{*}{$\begin{array}{l}\text { Black (51.65\%), } \\
\text { traspartent } \\
(27.78 \%), \text { blue } \\
(14.64 \%) \text {, red } \\
(5.93 \%)\end{array}$} & \multirow{12}{*}{$\begin{array}{l}\text { Long-range } \\
\text { transport, surface } \\
\text { runoff }\end{array}$} & \multirow[t]{12}{*}{ Liang et al. ${ }^{[61]}$} \\
\hline & Yibug Caka & 4559 & & & & & $\begin{array}{l}2643.65 \pm \\
1716.25 \text { items } / \mathrm{kg}\end{array}$ & & & & & \\
\hline & $\begin{array}{l}\text { Tangqung } \\
\text { Co }\end{array}$ & 4469 & & & & & $\begin{array}{l}269.26 \pm \\
371.98 \text { items/kg }\end{array}$ & & & & & \\
\hline & Dagze Co & 4472 & & & & & $\begin{array}{l}507.51 \pm \\
543.06 \text { items/kg }\end{array}$ & & & & & \\
\hline & Chaxiabu Co & 4499 & & & & & $\begin{array}{l}701.89 \pm \\
227.02 \text { items } / \mathrm{kg}\end{array}$ & & & & & \\
\hline & $\begin{array}{l}\text { Guojialun } \\
\text { Co }\end{array}$ & 4532 & & & & & $\begin{array}{l}185.55 \pm \\
265.56 \text { items/kg }\end{array}$ & & & & & \\
\hline & Pongcê Co & 4536 & & & & & $\begin{array}{l}250.12 \pm \\
412.68 \text { items/kg }\end{array}$ & & & & & \\
\hline & Bangkog Co & 4531 & & & & & $\begin{array}{l}297.39 \pm \\
61.87 \text { items/kg }\end{array}$ & & & & & \\
\hline & Gogen Co & 4675 & & & & & $\begin{array}{l}640.94 \pm \\
157.70 \text { items } / \mathrm{kg}\end{array}$ & & & & & \\
\hline & Bobsêr & 4609 & & & & & $\begin{array}{l}143.45 \pm \\
268.38 \text { items/kg }\end{array}$ & & & & & \\
\hline & $\begin{array}{l}\text { Yangnapeng } \\
\text { Co }\end{array}$ & 4633 & & & & & $\begin{array}{l}17.22 \pm \\
29.66 \text { items/kg }\end{array}$ & & & & & \\
\hline & Angdaer Co & 4854 & & & & & $\begin{array}{l}389.03 \pm \\
505.71 \text { items/kg }\end{array}$ & & & & & \\
\hline India & Anchar Lake & 1583 & Sediment & Van Veen grab & $\begin{array}{l}\text { Stereomicroscope, } \\
\text { ATR-FTIR }\end{array}$ & $\begin{array}{l}\text { PA, PET, PS, } \\
\text { PVC, PP }\end{array}$ & 606 items $/ \mathrm{kg}$ & $\begin{array}{l}\text { Fibres, films, } \\
\text { fragments }\end{array}$ & $\begin{array}{l}30- \\
2000\end{array}$ & $\begin{array}{l}\text { White (51\%), red } \\
(26 \%), \text { black } \\
(8 \%), \text { blue }(8 \%), \\
\text { yellow }(5 \%), \\
\text { green }(2 \%)\end{array}$ & $\begin{array}{l}\text { Anthropogentic } \\
\text { activities }\end{array}$ & $\begin{array}{l}\text { Neelavannan et } \\
\text { al. }^{[62]}\end{array}$ \\
\hline \multirow[t]{2}{*}{ Russia } & $\begin{array}{l}\text { Dzhulukul } \\
\text { Lake }\end{array}$ & 2199 & Surface water & Glass jars & SEM/EDS & ND & 5 items $/ \mathrm{L}$ & $\begin{array}{l}\text { Fragments, } \\
\text { foams }\end{array}$ & $\begin{array}{l}0.06- \\
0.48\end{array}$ & ND & \multirow[t]{2}{*}{$\begin{array}{l}\text { Anthropogentic } \\
\text { activities }\end{array}$} & \multirow[t]{2}{*}{ Malygina et al. ${ }^{[65]}$} \\
\hline & Talmen Lake & 1531 & Surface water & & & & 8 items $/ \mathrm{L}$ & Foams, films & $\begin{array}{l}0.03- \\
0.12\end{array}$ & ND & & \\
\hline \multirow[t]{2}{*}{ Italy } & Dimon & 1872 & Snow & Steel spoon & $\mu-\mathrm{FTIR}$ & PET & $\begin{array}{l}0.11 \pm 0.19 \\
\text { items } / L\end{array}$ & Fragments & 220 & Blue & $\begin{array}{l}\text { Long-range } \\
\text { transport }\end{array}$ & \multirow[t]{2}{*}{ Pastorino et al. ${ }^{[13]}$} \\
\hline & & & Surface water & $\begin{array}{l}\text { Apstein net } \\
\text { (plankton) }\end{array}$ & & - & - & - & - & - & - & \\
\hline
\end{tabular}




\begin{tabular}{|c|c|c|c|c|c|c|c|c|c|c|c|c|}
\hline & & & Sediment & Van Veen grab & & - & - & - & - & - & - & \\
\hline & & & Macroinvertebrates & Surber net & & - & - & - & - & - & - & \\
\hline & & & Fish & Electrofishing & & - & - & - & - & - & - & \\
\hline Turkey & Crater & 2380 & Surface water & Glass bottles & SEM, $\mu$-Raman & $P E, P P$ & & Fragments & 15 & ND & $\begin{array}{l}\text { Anthropogentic } \\
\text { activities }\end{array}$ & Çomaklı et al. ${ }^{[67]}$ \\
\hline \multirow[t]{2}{*}{ Switzerland } & Sassolo & 2074 & Surface water & Glass bottles & $\begin{array}{l}\text { Optical } \\
\text { microscope, FTIR }\end{array}$ & $\begin{array}{l}\text { PB, PE, PET, } \\
\text { PMMA, PP, PS }\end{array}$ & 2.6 items $/ \mathrm{L}$ & $\begin{array}{l}\text { Pellets, } \\
\text { fragments, } \\
\text { films }\end{array}$ & $>125$ & ND & $\begin{array}{l}\text { Anthropogentic } \\
\text { activities }\end{array}$ & $\begin{array}{l}\text { Negrete Velasco } \\
\text { et al. }{ }^{[61]}\end{array}$ \\
\hline & & & Sediment & $\begin{array}{l}\text { Scraping with } \\
\text { plastic } \\
\text { containers }\end{array}$ & & $P E, P P$ & 33 items $/ \mathrm{kg}$ & Fibres & $\begin{array}{l}125- \\
500\end{array}$ & ND & $\begin{array}{l}\text { Anthropogentic } \\
\text { activities }\end{array}$ & \\
\hline \multirow[t]{3}{*}{ China } & Qinghai & 3260 & Surface water & Trawl net & $\begin{array}{l}\text { Stereomicroscope, } \\
\text { Raman }\end{array}$ & PP, PE, PET & $\begin{array}{l}180,900 \pm \\
229533 \\
\text { items } / \mathrm{km}^{2}\end{array}$ & $\begin{array}{l}\text { Fibres, } \\
\text { fragments, } \\
\text { foam, sheets }\end{array}$ & $\begin{array}{l}100- \\
500\end{array}$ & Trasparent, blue & Tourism & Xiong et al. ${ }^{[57]}$ \\
\hline & & & Sediment & $\begin{array}{l}\text { Stainless-steel } \\
\text { shovel }\end{array}$ & & $\begin{array}{l}\text { PP, PE, EVA, } \\
\text { PVC, nylon, } \\
\text { PC }\end{array}$ & $\begin{array}{l}50-1292 \\
\text { items } / \mathrm{m}^{2}\end{array}$ & $\begin{array}{l}\text { Fibres, } \\
\text { fragments, } \\
\text { foam, sheets }\end{array}$ & ND & ND & & \\
\hline & & & Fish & ND & & $\begin{array}{l}\text { PE, PS, PP, } \\
\text { nylon }\end{array}$ & $\begin{array}{l}5.4 \pm 3.6 \\
\text { items/specimen }\end{array}$ & $\begin{array}{l}\text { Fibres, } \\
\text { sheets }\end{array}$ & ND & ND & & \\
\hline \multirow[t]{4}{*}{ China } & Siling Co & 4530 & Sediment & Shovel & Raman, SEM & $P E, P P, P S$ & $\begin{array}{l}563 \pm 1219 \\
\text { items } / \mathrm{m}^{2}\end{array}$ & $\begin{array}{l}\text { Fragments, } \\
\text { sheet, foams }\end{array}$ & $\begin{array}{l}500- \\
1000\end{array}$ & ND & $\begin{array}{l}\text { Atmospheric } \\
\text { deposition }\end{array}$ & Zhang et al. ${ }^{[63]}$ \\
\hline & Geren Co & 5780 & & & & $\begin{array}{l}\text { PE, PP, PET, } \\
\text { PVC }\end{array}$ & $\begin{array}{l}42 \pm 47 \\
\text { items } / \mathrm{m}^{2}\end{array}$ & & $\begin{array}{l}500- \\
1000\end{array}$ & & & \\
\hline & Wuru Co & 4700 & & & & PP & $\begin{array}{l}117 \pm 126 \\
\text { items } / \mathrm{m}^{2}\end{array}$ & & $\begin{array}{l}500- \\
1000\end{array}$ & & & \\
\hline & Mujiu Co & 5306 & & & & $P P, P E$ & $17 \pm 20$ items $/ \mathrm{m}^{2}$ & & $\begin{array}{l}500- \\
1000\end{array}$ & & & \\
\hline Mongolia & Hovsgol & 1645 & Surface water & $\begin{array}{l}\text { Manta trawl } \\
\text { net }\end{array}$ & Optical microscope & & $\begin{array}{l}20,264 \\
\text { items } / \mathrm{km}^{2}\end{array}$ & $\begin{array}{l}\text { Fragments, } \\
\text { films, fibres }\end{array}$ & ND & ND & $\begin{array}{l}\text { Atmospheric } \\
\text { deposition, } \\
\text { tourism }\end{array}$ & Free et al. ${ }^{[33]}$ \\
\hline
\end{tabular}

Studies are reported from the most recent to the oldest date of publication. EVA: Ethylene-vinyl acetate; ND: not determined; PA: polyamide; PMMA: polymethylmethacrylate; PC: polycarbonate; PE: polyethylene; PEST: polyester; PET: polyethylene terephthalate; PP: polypropylene; PS: polystyrene; PTFE: polytetrafluoroethylene; PU: polyurethane; PVC: polyvinyl chloride; FTIR: Fourier-transform infrared spectroscopy; SEM: scanning electron microscopy; SEM/EDS: scanning electron microscopy and energy-dispersive X-ray spectroscopy.

Microplastic abundance varied widely between the studies (country of sampling) and matrices (mainly water and sediment). For example, Pastorino et al ${ }^{[13]}$ measured MP pollution in sediment samples from a high-mountain lake (Carnic Alps, Italy) and found no particles. Negrete Velasco et al. ${ }^{[61]}$ reported low (33 items $/ \mathrm{kg}$ ) occurrence in a remote uninhabited lake (Sassolo Lake, Switzerland). Recently, Neelavannan et al. ${ }^{[62]}$ found a mean of 606 items $/ \mathrm{kg}$ in Anchar Lake located in the Kashmir Valley (Himalaya, India). Zhang et al ${ }^{[63]}$ reported a range of $8-563$ items $/ \mathrm{m}^{2}$ in six high-mountain lakes of the Tibetan Plateau 


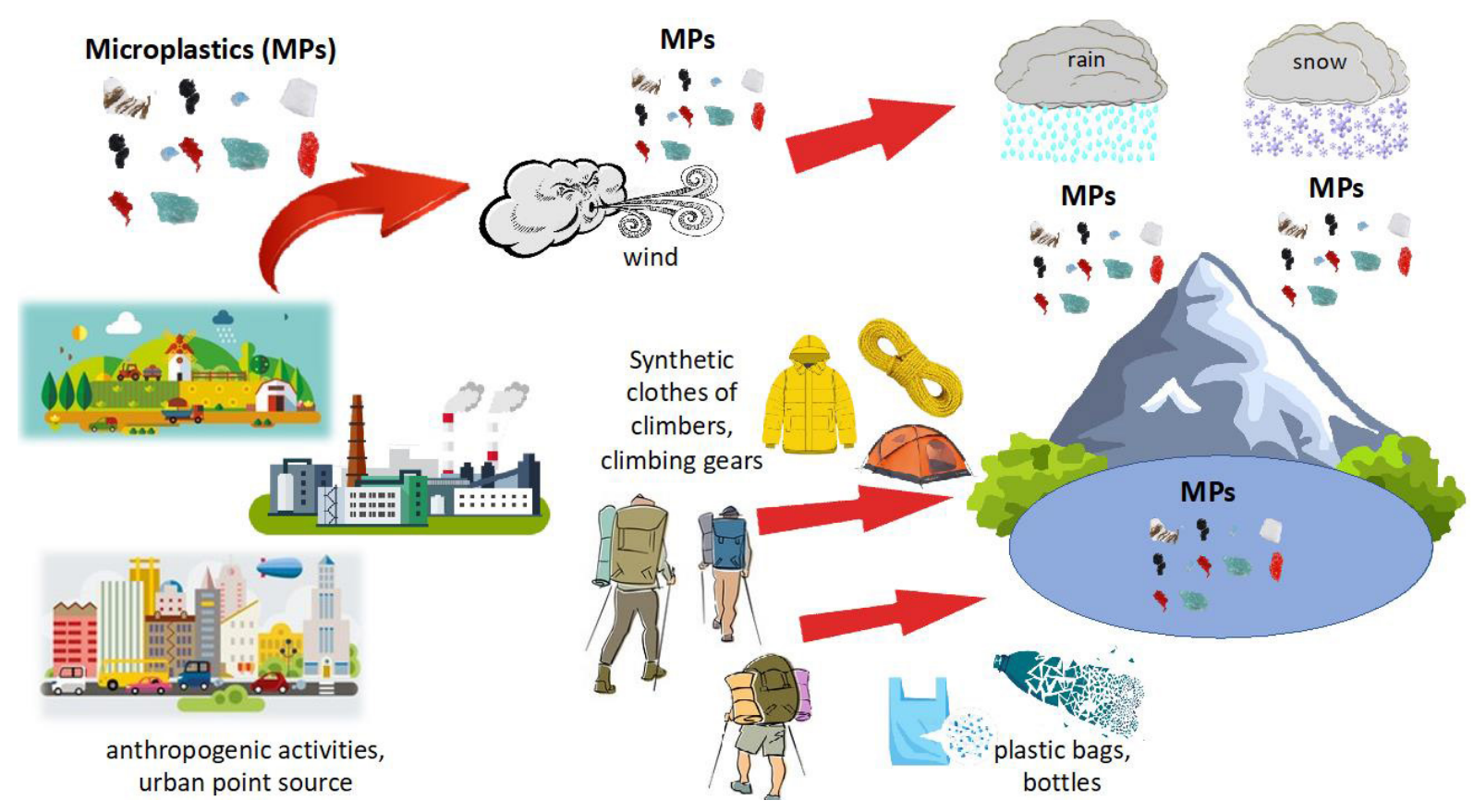

Figure 1. Main sources and transportation of microplastics in high-mountain lakes.

(China). A similar range (5.4-1292 items $/ \mathrm{m}^{2}$ ) was found in Qinghai Lake (Tibetan Plateau, China) by Xiong et al. ${ }^{[57]}$. Greater abundance (mean value: 2644 items $/ \mathrm{kg}$ ) was reported by Liang et al. ${ }^{[64]}$, who also measured MP occurrence in 12 lakes of the Tibetan Plateau.

There was also great variability in MP abundance in the water samples. Free et al.$^{[4]]}$ and Xiong et al. ${ }^{[57]}$ found high levels of MPs (20,264 and 180,900 particles/ $\mathrm{km}^{2}$, respectively). It should be noted, however, that both lakes are tourist campsites, which may explain their elevated MP pollution compared to the low values (5-8 particles/L) recorded by Malygina et al. ${ }^{[65]}$ in two remote lakes (Dzhulukul Lake and Talmetn Lake; Siberia, Russia) or the absence of particles in Dimon Lake (Carnic Alps, Italy) ${ }^{[13]}$.

Microplastics vary in size, shape, color, and polymer composition according to source, degradation, and residence period. Because of their many sources (e.g., urban, suburban, rural, and other sites), atmospheric MPs range widely in size and chemical composition ${ }^{[43]}$. Microplastics start to deteriorate in water. Abiotic processes, such as ultraviolet (UV) photooxidation combined with mechanical abrasion, gradually break the plastics down into fragments ${ }^{[66]}$. Xiong et al ${ }^{[57]}$ identified characteristic peaks (corresponding to $\mathrm{C}=\mathrm{O}$ ) in the Raman spectrum of MPs compared to virgin polymer, reflecting oxidative weathering of the particles. Zhang et al. ${ }^{[63]}$ found that particles 1000-5000 $\mu \mathrm{m}$ in size occurred most often in the sediment samples from seven remote lakes of the Tibetan Plateau (China). Neelavannan et al. ${ }^{[62]}$ reported that the most frequent MP size in the sediment samples from Anchar Lake (Himalaya) ranged between 300 and $1000 \mu \mathrm{m}$. Smaller particles (ranging 50-500 $\mu \mathrm{m}$ ) were reported in sediment samples by Liang et al.$^{[64]}$ in 12 remote lakes of the Tibetan Plateau. The same results were shared by Xiong et al. ${ }^{[57]}$ who reported MPs ranging in size between 100 and $500 \mu \mathrm{m}$ in both water and sediment samples from the high-altitude Qinghai Lake (China) and by Negrete Velasco et al. ${ }^{[61]}$ for Sassolo Lake (Switzerland), who recorded particles ranging in size between 125 and $500 \mu \mathrm{m}$. In Dimon Lake, a single particle measuring $220 \mu \mathrm{m}$ was detected in a snow sample ${ }^{[13]}$, while in the sediment samples of Crater Lake (Turkey) were 8-15 $\mu \mathrm{m}$ in size ${ }^{[67]}$, much smaller than those reported for other high-mountain lakes. Finally, the smallest particles $(0.03-0.48 \mu \mathrm{m})$ were recorded by Malygina et al. ${ }^{[6]}$ 
in two remote Siberian lakes. This may have been due to the oxidation and deterioration of plastic polymers by exposure to UV radiation. In addition, large variation in diurnal temperature may accelerate the dissipation of particles in small debris ${ }^{[63]}$.

On average, the colors typically recorded in most samples were white, transparent, blue, and black. The diversity of colors can be attributed to differences in origin and provide information about possible sources ${ }^{[68,69]}$. White MPs originate from packaging materials and tote bags ${ }^{[70]}$, while colored MPs are usually attributed to garments, ropes, and fishing nets ${ }^{[71]}$. Transparent MPs commonly result from fishing nets and lines $^{[72]}$.

Polypropylene (PP) and polyethylene (PE) were two frequent polymer types recorded in the samples from high-mountain lakes, and they are also common MP contaminants in European freshwater ecosystems ${ }^{[73]}$. Polyethylene is extensively used in packaging (e.g., plastic bags), while PP is used widely in everyday objects such as packaging trays, plastic bottles, household products, and battery cases, among others. Polypropylene has the lowest density $\left(0.90-0.92 \mathrm{~g} / \mathrm{cm}^{3}\right)$ of the resins used in packaging; this characteristic allows for atmospheric transport and deposition ${ }^{[43]}$. Polyamide (PA) and polyethylene terephthalate (PET) were also detected in several samples, indicating just how widespread these polymers have become. Polyamide is held together with amide bonds and therefore highly resistant to abrasion. Widely employed in textile manufacturing, it is also used in the automotive and transportation industries. Because polyamide fibers were originally developed as an alternative to silk, they are soft and flexible, which enhances wearing comfort, while PET is used in applications ranging from packaging to electronics.

The MPs from the high-mountain lakes came largely in the shape of fragments and fibers. The fragments displayed various surface features: sharp edges with cracks, rounded shapes with smooth surfaces, or degraded rough surfaces. Although the sources of the fragments were not identified, their appearance may be related to their origin or history of degradation in the environment ${ }^{[74]}$. In oligotrophic lakes, high UV penetration and decreased biofouling (shielding of plastics from UV radiation) can hasten the fragmentation rate of plastics ${ }^{[75]}$, while duration of the ice cover may also influence MP degradation. Since high-mountain lakes with a short ice-free season are far less exposed to UV radiation, plastic degradation rates are slower there ${ }^{[43]}$.

Fiber can come from a variety of sources, including fishing, shipping, and textiles ${ }^{[6,77]}$. Anthropogenic sources of MP fiber pollution were associated with tourist access points, campsites, and recreational $\operatorname{areas}^{[33,57]}$. Due to a lack of outflow of water from the lake, Qinghai Lake has copious fiber deposits generated by tourism and acts as a sink for MP accumulation ${ }^{[5]}$.

The major mechanisms for MP occurrence in the remote, high-mountain Dimon Lake are thought to be atmospheric depositions ${ }^{[13]}$. Liang et al. ${ }^{[64]}$ suggested that atmospheric long-range transport, glacial meltwater, and surface runoff are potential pathways for carrying MPs from elsewhere to remote lakes in Tibet. Microplastics were detected in Lake Crater (Turkey), which is far from settlement sites ${ }^{[67]}$; because of their low specific density, they are transported to higher altitudes via wind currents, and then settle over sediments during precipitation events ${ }^{[51]}$. In addition, Zhang et al. ${ }^{[63]}$ suggested that wind currents of the Tibetan Plateau facilitate the deposition of MPs and the formation of mechanical erosion processes.

The isolated Sassolo Lake is inhabited; during the winter, it is covered by a $3 \mathrm{~m}$ thick ice sheet. Hiking, diving, pasturing, and other human activities are the primary causes of MP pollution ${ }^{[6]}$. The same conclusions were also shared by Malygina et al. ${ }^{[65]}$ in two remote Siberian lakes without permanent 
populations, in which concentrations and configuration of MPs depend on local human activities (fishing, transport, landfilling). Finally, Neelavannan et al. ${ }^{[62]}$ reported that the MPs in Anchar Lake have a complex source derived mostly from the automobile, textile, and packaging industries.

\section{CONCLUDING REMARKS AND FUTURE PERSPECTIVES}

This minireview summarizes current research on MP pollution in high-mountain lakes, which are considered a good indicator of global change in mountain ecosystems. Mountainous ecosystems have a significant impact on global climate change and are essential natural resources. Knowledge about MP occurrence in these pristine ecosystems is important.

Generally, variations among research groups are found in all sampling steps. For instance, there is no standard net, pore, or mesh size, leading to different sizes of MPs being sampled in each study. Representativeness and reproducibility of most results is uncertain, amplified by uncareful methodology descriptions lacking important details, such as volume of samples. Moreover, the detection technique to identify MPs was noted to progress from early to later studies. Thus, there is an urgent need for a validated, quick, and simple methodology.

Microplastic occurrence in high-altitude ecosystems such as glaciers, snow, and lakes may lead to biodiversity loss and disease. The abundance of MPs in the remote lakes of the Tibetan Plateau is cause for environmental concern ${ }^{[6]]}$ since particles can contaminate water for drinking or agricultural purposes. In addition, the high concentration of MPs found in lake sediments can have a negative effect on the health of local inhabitants and aquatic life.

Moreover, the ecology and physiology of aquatic organisms may be impacted by $\mathrm{MPs}^{[78,79]}$. Although highmountain lakes were originally fishless ${ }^{[2]}$, other native organisms such as phytoplankton and zooplankton or aquatic macroinvertebrates can interact with plastic particles ${ }^{[80]}$. Blocked gills and intestinal obstruction are known to lead to a reduction in the size of aquatic organisms and result in diseases ${ }^{[8,82]}$. Microplastics are often composed of a complex mixture of chemicals, namely additives and monomers in the ingredients of the plastic material and byproducts of manufacturing, and chemical contaminants in water accumulate on plastic when it becomes litter (i.e., persistent organic pollutants and metals), with serious consequences for the life of aquatic organisms ${ }^{[1,82]}$.

The material, shape, and color of particles found in remote lakes point to tourism as a major source of MP pollution. Frequently found in all samples, PP and PE are mainly used for food packaging, and supplies and are often carelessly left behind by tourists.

Because MPs are ubiquitous in many ecosystems, global collaborative efforts are needed to investigate their abundance and potential sources in ecosystems, particularly environments at high elevation. In addition, corrective/intervention measures are needed. For example, the Sagarmatha Pollution Control Committee recently began plastic trash removal operations, while other activities to remove visible waste deposits on Mount Everest are also underway (https://adventuretravelconservationfund.org). Public agencies should encourage greater awareness of plastic waste management and recycling among tourists and climbers. Citizen science programs should be encouraged to equip community members with knowledge, skills, and confidence to participate in enjoyable scientific research activities while generating data to inform sustainable community solution ${ }^{[83]}$. Moreover, national framework strategies for managing plastic waste should be implemented in these sensitive ecosystems ${ }^{[84]}$. 
For these reasons, priority should be given to research to better understand the occurrence, source, and pathways of MP pollution in high-mountain lakes:

- Atmospheric deposition and transport of MPs in remote areas, linked with data on precipitation, wind speed, and direction;

- Impact of natural fibers on aquatic ecosystems as substitutes of synthetics in climbing and trekking gear;

- Impact of high-mountain lake water on downstream freshwater ecosystems;

- Impact of MPs on native aquatic species (e.g., macroinvertebrates) by (eco)toxicological testing;

- Trophic transfer of MPs along aquatic food webs in high-mountain lakes.

\section{DECLARATIONS}

Authors' contributions

Conceptualization, data curation, methodology, writing - original draft: Pastorino P

Conceptualization, methodology, writing - reviewing and editing: Prearo M, Pizzul E, Elia AC, Renzi M, Ginebreda A, Barceló D

Supervision: Barceló D

\section{Availability of data and materials}

Not applicable.

\section{Financial support and sponsorship}

None.

\section{Conflicts of interest}

All authors declared that there are no conflicts of interest.

\section{Ethical approval and consent to participate}

Not applicable.

\section{Consent for publication}

Not applicable.

\section{Copyright}

(c) The Author(s) 2022.

\section{REFERENCES}

1. Catalan J, Camarero L, Felip M, et al. High mountain lakes: extreme habitats and witnesses of environmental changes. Limnetica 2006;25:551-84. DOI

2. Pastorino P, Prearo M. High-mountain lakes, indicators of global change: ecological characterization and environmental pressures. Diversity 2020;12:260. DOI

3. Moser K, Baron J, Brahney J, et al. Mountain lakes: eyes on global environmental change. Glob Planet Change 2019;178:77-95. DOI

4. Rossetti G, Ferrari I, Marchetto A, et al. Ricerche ecologiche in laghi d'alta quota del bacino padano. Biologia Ambientale 2010;24:179-86. DOI

5. Oleksy IA, Beck WS, Lammers RW, et al. The role of warm, dry summers and variation in snowpack on phytoplankton dynamics in mountain lakes. Ecology 2020;101:e03132. DOI PubMed PMC

6. Tiberti R, Buscaglia F, Armodi M, et al. Mountain lakes of Mont Avic Natural Park: ecological features and conservation issues. $J$ Limnol 2019;79:43-58. DOI 
7. Selene P, Paolo P, Marco B, et al. Changes in midge assemblages (Diptera Chironomidae) in an alpine lake from the Italian Western Alps: the role and importance of fish introduction. Hydrobiologia 2020;847:2393-415. DOI

8. Rogora M, Frate L, Carranza ML, et al. Assessment of climate change effects on mountain ecosystems through a cross-site analysis in the Alps and Apennines. Sci Total Environ 2018;624:1429-42. DOI PubMed

9. Camarero L, Botev I, Muri G, Psenner R, Rose N, Stuchlik E. Trace elements in alpine and arctic lake sediments as a record of diffuse atmospheric contamination across Europe. Freshwater Biology 2009;54:2518-32. DOI

10. Felipe-Sotelo M, Tauler R, Vives I, Grimalt JO. Assessment of the environmental and physiological processes determining the accumulation of organochlorine compounds in European mountain lake fish through multivariate analysis (PCA and PLS). Sci Total Environ 2008;404:148-61. DOI PubMed

11. Pastorino P, Prearo M, Bertoli M, et al. Accumulation of $\mathrm{As}, \mathrm{Cd}, \mathrm{Pb}$, and $\mathrm{Zn}$ in sediment, chironomids and fish from a high-mountain lake: first insights from the Carnic Alps. Sci Total Environ 2020;729:139007. DOI PubMed

12. Vieira Y, Lima EC, Foletto EL, Dotto GL. Microplastics physicochemical properties, specific adsorption modeling and their interaction with pharmaceuticals and other emerging contaminants. Sci Total Environ 2021;753:141981. DOI PubMed

13. Pastorino P, Pizzul E, Bertoli M, et al. First insights into plastic and microplastic occurrence in biotic and abiotic compartments, and snow from a high-mountain lake (Carnic Alps). Chemosphere 2021;265:129121. DOI PubMed

14. Ghayebzadeh M, Aslani H, Taghipour H, Mousavi S. Estimation of plastic waste inputs from land into the Caspian Sea: a significant unseen marine pollution. Mar Pollut Bull 2020;151:110871. DOI PubMed

15. Kumar R, Sharma P, Manna C, Jain M. Abundance, interaction, ingestion, ecological concerns, and mitigation policies of microplastic pollution in riverine ecosystem: a review. Sci Total Environ 2021;782:146695. DOI

16. Tang Y, Liu Y, Chen Y, et al. A review: research progress on microplastic pollutants in aquatic environments. Sci Total Environ 2021;766:142572. DOI PubMed

17. Plastic Europe. Plastics-the facts 2013: an analysis of European latest plastics production, demand and waste data. Available from: https://plasticseurope.org/wp-content/uploads/2021/10/2013-Plastics-the-facts.pdf [Last accessed on 18 Feb 2021].

18. Plastics Europe. An analysis of European plastics production, demand and waste data. Available from: https://plasticseurope.org/it/wpcontent/uploads/sites/5/2021/11/Plastics_the_facts-WEB-2020_versionJun21_final-1.pdf [Last accessed on 18 Feb 2021].

19. Thompson RC, Swan SH, Moore CJ, vom Saal FS. Our plastic age. Philos Trans R Soc Lond B Biol Sci 2009;364:1973-6. DOI PubMed PMC

20. Gigault J, Halle AT, Baudrimont M, et al. Current opinion: what is a nanoplastic? Environ Pollut 2018;235:1030-4. DOI PubMed

21. Singh B, Sharma N. Mechanistic implications of plastic degradation. Polymer Degradation and Stability 2008;93:561-84. DOI

22. Zhang K, Hamidian AH, Tubić A, et al. Understanding plastic degradation and microplastic formation in the environment: a review. Environ Pollut 2021;274:116554. DOI PubMed

23. Ru J, Huo Y, Yang Y. Microbial degradation and valorization of plastic wastes. Front Microbiol 2020;11:442. DOI PubMed PMC

24. Mateos-Cárdenas A, O'Halloran J, van Pelt FNAM, Jansen MAK. Rapid fragmentation of microplastics by the freshwater amphipod Gammarus duebeni (Lillj.). Sci Rep 2020;10:12799. DOI PubMed PMC

25. Danso D, Chow J, Streit WR. Plastics: environmental and biotechnological perspectives on microbial degradation. Appl Environ Microbiol 2019;85:e01095-19. DOI PubMed PMC

26. Crawford CB, Quinn B. Microplastic pollutants. 1 ed. Amsterdam: Elsevier Limited; 2017. p. 1-336. DOI

27. Qi R, Jones DL, Li Z, Liu Q, Yan C. Behavior of microplastics and plastic film residues in the soil environment: a critical review. Sci Total Environ 2020;703:134722. DOI PubMed

28. Huang D, Xu Y, Lei F, et al. Degradation of polyethylene plastic in soil and effects on microbial community composition. J Hazard Mater 2021;416:126173. DOI PubMed

29. Lv X, Dong Q, Zuo Z, Liu Y, Huang X, Wu W. Microplastics in a municipal wastewater treatment plant: Fate, dynamic distribution, removal efficiencies, and control strategies. J Clean Prod 2019;225:579-86. DOI

30. Wong JKH, Lee KK, Tang KHD, Yap PS. Microplastics in the freshwater and terrestrial environments: Prevalence, fates, impacts and sustainable solutions. Sci Total Environ 2020;719:137512. DOI PubMed

31. Raju S, Carbery M, Kuttykattil A, et al. Improved methodology to determine the fate and transport of microplastics in a secondary wastewater treatment plant. Water Res 2020;173:115549. DOI PubMed

32. Murphy F, Ewins C, Carbonnier F, Quinn B. Wastewater treatment works (WwTW) as a source of microplastics in the aquatic environment. Environ Sci Technol 2016;50:5800-8. DOI PubMed

33. Free CM, Jensen OP, Mason SA, Eriksen M, Williamson NJ, Boldgiv B. High-levels of microplastic pollution in a large, remote, mountain lake. Mar Pollut Bull 2014;85:156-63. DOI PubMed

34. Unice KM, Weeber MP, Abramson MM, et al. Characterizing export of land-based microplastics to the estuary - Part II: sensitivity analysis of an integrated geospatial microplastic transport modeling assessment of tire and road wear particles. Sci Total Environ 2019;646:1650-9. DOI PubMed

35. Piñon-Colin TJ, Rodriguez-Jimenez R, Rogel-Hernandez E, Alvarez-Andrade A, Wakida FT. Microplastics in stormwater runoff in a semiarid region, Tijuana, Mexico. Sci Total Environ 2020;704:135411. DOI PubMed

36. Yonkos LT, Friedel EA, Perez-Reyes AC, Ghosal S, Arthur CD. Microplastics in four estuarine rivers in the Chesapeake Bay, U.S.A. Environ Sci Technol 2014;48:14195-202. DOI PubMed

37. Lacerda ALDF, Rodrigues LDS, van Sebille E, et al. Plastics in sea surface waters around the Antarctic Peninsula. Sci Rep 2019;9:3977. DOI PubMed PMC

38. Dris R, Gasperi J, Saad M, Mirande C, Tassin B. Synthetic fibers in atmospheric fallout: a source of microplastics in the environment? 
Mar Pollut Bull 2016;104:290-3. DOI PubMed

39. Huang Z, Weng Y, Shen Q, Zhao Y, Jin Y. Microplastic: a potential threat to human and animal health by interfering with the intestinal barrier function and changing the intestinal microenvironment. Sci Total Environ 2021;785:147365. DOI PubMed

40. Jiménez-Skrzypek G, Hernández-Sánchez C, Ortega-Zamora C, González-Sálamo J, González-Curbelo MÁ, Hernández-Borges J. Microplastic-adsorbed organic contaminants: analytical methods and occurrence. Trends Analyt Chem 2021;136:116186. DOI

41. Zhang Y, Gao T, Kang S, Sillanpää M. Importance of atmospheric transport for microplastics deposited in remote areas. Environ Pollut 2019;254:112953. DOI PubMed

42. Zhang Y, Gao T, Kang S, Allen S, Luo X, Allen D. Microplastics in glaciers of the Tibetan Plateau: evidence for the long-range transport of microplastics. Sci Total Environ 2021;758:143634. DOI PubMed

43. Allen S, Allen D, Phoenix VR, et al. Atmospheric transport and deposition of microplastics in a remote mountain catchment. Nat Geosci 2019;12:339-44. DOI

44. Obbard RW, Sadri S, Wong YQ, Khitun AA, Baker I, Thompson RC. Global warming releases microplastic legacy frozen in Arctic Sea ice. Earth's Future 2014;2:315-20. DOI

45. Esposito G, Prearo M, Renzi M, et al. Occurrence of microplastics in the gastrointestinal tract of benthic by-catches from an eastern Mediterranean deep-sea environment. Mar Pollut Bull 2022;174:113231. DOI PubMed

46. Fang C, Zheng R, Zhang Y, et al. Microplastic contamination in benthic organisms from the Arctic and sub-Arctic regions. Chemosphere 2018;209:298-306. DOI PubMed

47. Ambrosini R, Azzoni RS, Pittino F, Diolaiuti G, Franzetti A, Parolini M. First evidence of microplastic contamination in the supraglacial debris of an alpine glacier. Environ Pollut 2019;253:297-301. DOI PubMed

48. Cabrera M, Valencia BG, Lucas-solis O, et al. A new method for microplastic sampling and isolation in mountain glaciers: a case study of one antisana glacier, Ecuadorian Andes. Case Studies in Chemical and Environmental Engineering 2020;2:100051. DOI

49. Parolini M, De Felice B, Lamonica C, et al. Macroplastics contamination on glaciers from Italian Central-Western Alps. Environmental Advances 2021;5:100084. DOI

50. Pittino F, Ambrosini R, Azzoni R, et al. Post-depositional biodegradation processes of pollutants on glacier surfaces. Condensed Matter 2018;3:24. DOI

51. Coe JM, Rogers D. Marine debris: sources, impacts, and solutions. Springer Science \& Business Media; 2012. p. 1-432. DOI

52. Cai L, Wang J, Peng J, et al. Characteristic of microplastics in the atmospheric fallout from Dongguan city, China: preliminary research and first evidence. Environ Sci Pollut Res Int 2017;24:24928-35. DOI PubMed

53. Klein M, Fischer EK. Microplastic abundance in atmospheric deposition within the Metropolitan area of Hamburg, Germany. Sci Total Environ 2019;685:96-103. DOI PubMed

54. Liu C, Li J, Zhang Y, et al. Widespread distribution of PET and PC microplastics in dust in urban China and their estimated human exposure. Environ Int 2019;128:116-24. DOI PubMed

55. Napper IE, Davies BF, Clifford H, et al. Reaching new heights in plastic pollution-preliminary findings of microplastics on mount everest. One Earth 2020;3:621-30. DOI

56. Stefánsson H, Peternell M, Konrad-Schmolke M, Hannesdóttir H, Ásbjörnsson EJ, Sturkell E. Microplastics in glaciers: first results from the Vatnajökull ice cap. Sustainability 2021;13:4183. DOI

57. Xiong X, Zhang K, Chen X, Shi H, Luo Z, Wu C. Sources and distribution of microplastics in China's largest inland lake - Qinghai Lake. Environ Pollut 2018;235:899-906. DOI PubMed

58. Prata JC, da Costa JP, Duarte AC, Rocha-santos T. Methods for sampling and detection of microplastics in water and sediment: a critical review. Trends Analyt Chem 2019;110:150-9. DOI

59. Lavers JL, Oppel S, Bond AL. Factors influencing the detection of beach plastic debris. Mar Environ Res 2016;119:245-51. DOI PubMed

60. Hidalgo-Ruz V, Gutow L, Thompson RC, Thiel M. Microplastics in the marine environment: a review of the methods used for identification and quantification. Environ Sci Technol 2012;46:3060-75. DOI PubMed

61. Negrete Velasco ADJ, Rard L, Blois W, et al. Microplastic and fibre contamination in a remote mountain lake in Switzerland. Water 2020;12:2410. DOI

62. Neelavannan K, Sen IS, Lone AM, Gopinath K. Microplastics in the high-altitude Himalayas: assessment of microplastic contamination in freshwater lake sediments, Northwest Himalaya (India). Chemosphere 2022;290:133354. DOI PubMed

63. Zhang K, Su J, Xiong X, Wu X, Wu C, Liu J. Microplastic pollution of lakeshore sediments from remote lakes in Tibet plateau, China. Environ Pollut 2016;219:450-5. DOI PubMed

64. Liang T, Lei Z, Fuad MTI, et al. Distribution and potential sources of microplastics in sediments in remote lakes of Tibet, China. Sci Total Environ 2022;806:150526. DOI PubMed

65. Malygina N, Mitrofanova E, Kuryatnikova N, et al. Microplastic pollution in the surface waters from plain and mountainous lakes in Siberia, Russia. Water 2021;13:2287. DOI

66. Ter Halle A, Ladirat L, Gendre X, et al. Understanding the fragmentation pattern of marine plastic debris. Environ Sci Technol 2016;50:5668-75. DOI PubMed

67. Çomaklı E, Bingöl MS, Bilgili A. Assessment of microplastic pollution in a crater lake at high altitude: a case study in an urban crater lake in Erzurum, Turkey. Water Air Soil Pollut 2020;231:275. DOI

68. Sathish N, Jeyasanta KI, Patterson J. Abundance, characteristics and surface degradation features of microplastics in beach sediments of five coastal areas in Tamil Nadu, India. Mar Pollut Bull 2019;142:112-8. DOI PubMed

69. Nelms SE, Galloway TS, Godley BJ, Jarvis DS, Lindeque PK. Investigating microplastic trophic transfer in marine top predators. 
Environ Pollut 2018;238:999-1007. DOI PubMed

70. Cole M, Webb H, Lindeque PK, Fileman ES, Halsband C, Galloway TS. Isolation of microplastics in biota-rich seawater samples and marine organisms. Sci Rep 2014;4:4528. DOI PubMed PMC

71. Kumar VE, Ravikumar G, Jeyasanta KI. Occurrence of microplastics in fishes from two landing sites in Tuticorin, South east coast of India. Mar Pollut Bull 2018;135:889-94. DOI PubMed

72. Peng G, Zhu B, Yang D, Su L, Shi H, Li D. Microplastics in sediments of the Changjiang Estuary, China. Environ Pollut 2017;225:283-90. DOI PubMed

73. Cera A, Cesarini G, Scalici M. Microplastics in freshwater: what is the news from the world? Diversity 2020;12:276. DOI

74. Tanaka K, Takada H. Microplastic fragments and microbeads in digestive tracts of planktivorous fish from urban coastal waters. Sci Rep 2016;6:34351. DOI PubMed PMC

75. Andrady AL. Microplastics in the marine environment. Mar Pollut Bull 2011;62:1596-605. DOI PubMed

76. Claessens M, De Meester S, Van Landuyt L, De Clerck K, Janssen CR. Occurrence and distribution of microplastics in marine sediments along the Belgian coast. Mar Pollut Bull 2011;62:2199-204. DOI PubMed

77. Napper IE, Thompson RC. Release of synthetic microplastic plastic fibres from domestic washing machines: effects of fabric type and washing conditions. Mar Pollut Bull 2016;112:39-45. DOI PubMed

78. Trestrail C, Walpitagama M, Hedges C, et al. Foaming at the mouth: ingestion of floral foam microplastics by aquatic animals. Sci Total Environ 2020;705:135826. DOI PubMed

79. Li W, Chen X, Li M, Cai Z, Gong H, Yan M. Microplastics as an aquatic pollutant affect gut microbiota within aquatic animals. $J$ Hazard Mater 2022;423:127094. DOI PubMed

80. Piccardo M, Bertoli M, Pastorino P, et al. Lethal and sublethal responses of Hydropsyche pellucidula (Insecta, Trichoptera) to commercial polypropylene microplastics after different preconditioning treatments. Toxics 2021;9:256. DOI PubMed PMC

81. Ma H, Pu S, Liu S, Bai Y, Mandal S, Xing B. Microplastics in aquatic environments: toxicity to trigger ecological consequences. Environ Pollut 2020;261:114089. DOI PubMed

82. Hirt N, Body-Malapel M. Immunotoxicity and intestinal effects of nano- and microplastics: a review of the literature. Part Fibre Toxicol 2020;17:57. DOI PubMed PMC

83. Barceló D, Picó Y. Microplastics in the global aquatic environment: analysis, effects, remediation and policy solutions. $J$ Environ Chem Eng 2019;7:103421. DOI

84. Barcelo D, Pico Y. Case studies of macro- and microplastics pollution in coastal waters and rivers: is there a solution with new removal technologies and policy actions? Case Studies in Chemical and Environmental Engineering 2020;2:100019. DOI 